\title{
Understanding The “Dance" In Radical Screendance
}

Anna Heighway

There was a time when screendance implied a dancing body. The "dance" may have taken the shape of formal vocabulary or a looser interpretation of movement as dance, but common to either approach would have been the sight of humans in motion. Certain recent screendance films, however, such as David Hinton's Birds (2000), Becky Edmunds's This Place (2008), and Constantini Georgescu's Spin (2009) are void of human presence. Screendance artist Chirstinn Whyte observes the effects that these changes have had on current practice. She writes, "Networks and alliances are currently running ahead of established models, with initiatives springing up between the fault lines separating old from new, and reshaping the form at an accelerated pace."1 Yet whilst screendance making revels in the freedom of reconceptualization and reinvention, questions arise with regard to the experience of viewing, namely: what is the "dance" in screendance now that the human body has left center stage, and do audiences have the requisite concepts to identify and appreciate works that have outgrown traditional models? This paper investigates just what is required of viewers' perceptions that might allow them access to screendance today. It also explores the field's current relationship with dance through an analysis of those works that lie at screendance's outermost edges, which here shall be referred to as "Radical Screendance."

The tale of the genesis of screendance has long cemented our association of the field with the dancing human. This story usually embarks at the moment when the birth of cinema and dance coalesced in Thomas Edison's Annabelle the Dancer (189495). Two divergent paths are then posited: one mainstream, exemplified by the likes of Busby Berkley's 1930s Hollywood epics; and the other experimental, through American avant-gardists' works such as A Study in Choreography for the Camera (1945) by Maya Deren. The historical thread, either way, establishes a model of screendance in which an audience's recognition and appreciation necessitates the presence of people unquestionably consumed within the act of dancing.

The moment of screendance's move towards a broader definition is more difficult to pinpoint. However, it is clear that the conceptual changes that led to a remarking of boundaries originated at the epicenter of screendance itself-that is, through a perceptual shift from within a community of filmmakers, pedagogues, curators, and academics, which I will call "The Republic of Screendance." The Republic's refocusing of the dance in screendance away from the dancing figure and onto human motion provides an alternative history for screendance that begins with works such as Eadweard Muybridge's famous Motion Studies (1879). In this looser screendance model, the filmmaker need not frame the pirouette, but could explore more natural, non-theatrical forms of human motion such as running, falling, or the throwing of a 
punch. This new lineage facilitated an even more liberated screendance paradigm in which the "dance" in screendance need not be "dance" movement, nor human motion, but anything kinetically driven, full stop.

In 2010, Claudia Kappenberg and Douglas Rosenberg promoted these changes through the publication of their journal, The International Journal of Screendance. The introduction reads, "the journal supports scholarship intended to expand the parameters of what may currently be considered screendance." ${ }^{2}$ The direction of this expansion is highlighted through Kappenberg's line of questioning: "Does screendance need to look like dance?"3 Such questions have brought about a broad diversification in screendance practice. In addition, the screendance canon has experienced an expansion that borders on all-inclusion, as the reconceptualization of the dance in screendance has led to the re-classification of a whole host of vintage avant-garde films. The majority of these films do not portray the body in motion. The achievements of the early European avant-garde, such as Fernand Léger's, Ballet Mécanique (1924), René Clair's Entr'acte (1924), as well as that of Oskar Fishcingar (1900-1967), Walter Ruttman (1887-1941), Marcel Duchamp (1887-1968), Hans Richter (1888-1976), Man Ray (1890-1976), Eugene Deslaw (1898-1966), Lotte Reiniger (1899$1981)$ and those of the later wave; Len Lye (1901-1980), Shirley Clarke, (1919-1997) Ed Emshwiller (1925-199), Chick Strand (1931-2009), Norman McLaren (1914-1987) and Stan Brakhage (1933-2003) - to skim only the surface-now all fit under the rubric of screendance.

Such a rapid remodeling of screendance is not without its issues. When David Hinton pitched his proposals to make a screendance work made entirely from footage of birds, there was resistance. He noted, "The main issue about the film, seems to be, is it a dance film?"4 Filmmaker Becky Edmunds talks similarly of the field's reception of her observational style:

The work that I made, I feel very much related to dance ... but one of my problems was where to show my work because although it was clear to me it came from dance, when I was submitting to the festivals that are called screendance festivals, they weren't taking the work, because there wasn't in there, movement that they could perceive as dance. ${ }^{5}$

Four years ago the screendance community itself appears to have lacked the appropriate concepts to accept a human-free work as one of its own. Yet although screendance might now "get" itself, it is well worth probing these early responses to Radical work, as it foregrounds the nature of the issues that viewers might experience engaging with these works. Philosopher Graham McFee writes: "understanding, indeed, even seeing and hearing takes place under concepts ... what I see depends on the concepts I have."6 To understand Radical Screendance, viewers must therefore apply to it those concepts specific to Radical Screendance, as to attend to it via anything else would mean experiencing it as something different. ${ }^{7}$ The initial responses that Hinton and Edmund's work elicited typify this misapprehension, recalling similar moments in art history when audiences have not been ready to access 
radical work, from the opening night of Nijinsky's Le Sacre du Printemps (1913) to the birth of Duchamp's "Readymades" or Yvonne Rainer's post-modern dance. With the evolution of a practice comes the abandonment of its old models, which, no longer representative of current ideology, become outmoded constraints. It follows that if audiences are to engage with Radical Screendance, they need to acquire concepts of understanding that are relevant to the field in its current form. The reason for the Republic's reticence with Birds is that they were, at that time, invested in an interpretation of dance as human movement. The key to unlocking concepts for understanding Radical Screendance, therefore, requires an exploration of our own understandings of the term "dance."

We need only ask ourselves whether dance would exist without people to understand our historic claim to it. Rosenberg writes, "Dance lives in the body." McFee, likewise, refers to it as "a form of human behavior." stressed, be it expressive, functional, or performative, human agency is intrinsic to this account of dance. For, as Sue Jones points out, "we cannot perform dance without our knowledge nor by mistake,"10 as to dance is to partake in "intentional human action."11 It follows for Carr therefore that "plastic ballerinas, automatons or trained apes cannot and should not be said to dance in the strict sense that machines may be said to produce or perform music," because none are able to justifiably partake in this account of dance. According to these views, those screendance works that omit the human body cannot feasibly be concerned with dance. Something is clearly amiss. Either the filmmakers are wrong to attach the label "screendance" to these works, as are the Republic of Screendance in their authentication of these acts, or else there must be an alternative means of approaching the "dance" within screendance. The key lies in Carr's use of the words, "in the strict sense," for it hints at the possibility of other, less rigid ways of understanding the term, which might better serve as concepts for understanding Radical Screendance.

Dance as a flexible concept is an idea that has been explored by several philosophers. Sue Jones believes the term to hold "many layers of meaning"12 and Francis Sparshott likewise asserts that "there is no such thing as a complete knowledge of what dancing is"13; "there are innumerable understandings." ${ }^{14}$ This interpretable account of dance can be understood through reference to how we approach the term "dance" linguistically. Sparshott explains that it is, in fact, "peoples' normal usage of words which determines their meaning. ${ }^{15}$ Sparshott explains the diversity of dance accordingly: "The variations in our perspectives on what we recognise as our common practice of 'dance', or as versions of that practice, are negotiated by subtleties in our use of language." ${ }^{\prime 16} \mathrm{He}$ thus highlights the many perspectives of dance that we are capable of adopting, by nuancing the multifaceted relationship between the words that we use and the contexts to which they relate. Our language expresses a diverse attitude towards dance, therefore, through the direct, the synonymous, the associative, and the comparative, to name but a few. As Sparshott further writes, "Sometimes a word is the most appropriate name for a thing we are applying it to, sometime it is only one among many things it might be called, sometimes it is not 
meant to be literally correct but to be recognisable as a metaphor."17 This means that we "do use the word 'dance' in relation to the movements of swans, bees, butterflies and flowers"18 just as we could to the movement of "plastic ballerinas, automatons or trained apes."19 The disparity between Carr's arguments and this fact resides in our ability to apply the term not just to those things which are "unquestionably dance" or dance "in a strict sense," but also to "those that could be called dance." ${ }^{20}$ It is with this latter, pliant view of dance that we should situate Radical Screendance. As Latika Young, former festival coordinator for Dance Films Association writes, "We adopt an expansive view of what constitutes 'dance', a breadth of scope that is then also reflected in our curating decisions. We often screen films ... that have absolutely no conventional dance in the traditional sense." ${ }^{21}$ This ability to take a malleable approach towards dance is essential to this study, for it suggests that we might already have in our grasp some of the most vital concepts required for an understanding of Radical Screendance.

A further concept for an appreciation of Radical Screendance requires that viewers approach its works using mind over sight. As Amy Greenfield states, a screendance work "may not 'look like' a dance," but has the "meanings of dance." ${ }^{22}$ The suggestion here is that we might not be able to identify the "dance" in screendance based on sight alone; rather, our concepts for appreciation might reside somewhere out of eyes' reach. In order to access Radical Screendance, an audience has to probe deeper than the surface of things, as this cerebrally-driven field de-emphasizes the "recognizable," visible "doing" of dance, in favor of its conceptual basis. This move towards the conceptual is being driven by a corresponding move towards a more research-led approach to screendance practices that enable filmmakers to engage in an on-going interrogation of the potentialities of dance and filmmaking relations. As a result, the ideas of these artists become processed through their work in everinventive ways. As Kappenberg and Rosenberg note, "we aim to reframe dance as a form of research that examines the inter-relationships of composition, choreographic language, and meanings of body, movement, space and time." ${ }^{23}$ It is therefore common practice to find screendance makers referring to their work as "research." Becky Edmunds, for example, runs a "research-led screen dance practice, which seeks to deepen the screen application of dance practice," ${ }^{24}$ and Chirstinn Whyte speaks of her "microprojects" that "explore movement and time." ${ }^{25}$ Foregrounding the idea of research similarly serves to de-emphasize the materiality of the end product by privileging the conceptual and processual aspects of film and dance making.

Yet the more that the "dance" in Radical Screendance recedes into the minds of its makers-even when armed with the concepts outlined above-the more identifying a screendance from non-screendance can be problematic. An additional concept for accessing Radical Screendance, therefore, must be the intentions of the creators themselves. As McFee asserts, "intention seems crucial to avoiding misperception of ... artwork." ${ }^{26}$ There is, however, no question that intentionality in relation to screendance presents a number of issues, screendance's reclassification of avant-garde films being but one. As an area far beyond the reach of this paper, suffice 
it to say that for the purposes of the forthcoming exploration of works, the best possible interpretation is gleaned through an analysis of the works of Radical Filmmakers and the discourse through which they reference them.

\section{Screendance's Understandings Of Dance: The Works}

\section{Dance As Movement}

The following exploration of work uses appropriate concepts, as outlined above, to uncover some of the dance perspectives currently exercised in Radical Screendance. We begin with the dominant experience of dance valued as movement. Dance writer J. Anderson writes, "Dance is not simply a visual art, it is kinaesthetic as well; it appeals to our inherent sense of motion. ${ }^{.27}$ We can relate this interest to what Lorrettann Devlin Gascard refers to as our "kinetic urge." ${ }^{28}$ Dance perceived as movement becomes the ideal fix. Screendance, in turn, can be seen as a mining of the potentialities brought about through the inter-relationship between dance as motion and film-making.

A cinematic focus on motion can be traced back to the fine art of the avantgarde. Despite its immense range, one concern common to the early avant-garde painters was the desire to convey temporality. This aim eventually brought the focus onto motion, as movement, being a temporal phenomenon, necessitated the passing of time. This, in turn led to the development of novel pictorial styles and techniques. Fernand Léger speaks of "the introduction of mobile perspective, the sequential depiction of movement." 29 The advent of cinema created a bespoke medium for realizing these aims, for "film renders the world in motion ... movement, is the alpha and omega of the medium." ${ }^{\prime 30}$ The result was a whole host of films which preceded screendance's use of the cinematic process to manipulate and initiate motion. In much of this canon, furthermore, we find the beginnings of Radical Screendance's use of non-human movement to nuance dance.

The techniques that early avant-garde filmmakers used to affect movement from non-human subjects varied. Some artists approached cinematography with a fine art sensibility, whilst others embraced the possibilities of film-making more exclusively through editing techniques. The former approach involved drawing or painting abstract forms, which when passed through a projector became animated illusions of motion. Many such films drew on an interchange of formal concepts between music, dance, and cinema, to create a "pure," "absolute film" of visual rhythms. ${ }^{31}$ Walter Ruttmann's Lichtspiel Opus I (1921) for example, sets all manner of hand-painted blobs, points and swirls, morphing, dabbing, and colliding to the accompaniment of Max Butting. Len Lye, in his films, Colour Box (1935) for the General Post Office and Colour Flight (1937) for Imperial Airways, used camera-less techniques, scratching and stenciling forms directly onto film stock. The final effect was a similar dance of colorful shapes, which pulsated to the popular big band music of the era. An analogous exploration of music, dance, and cinema was portrayed by Hans Richter, Oskar Fischinger, Viking Eggeling, and Norman Mclaren, enjoying an especially 
memorable commercial success through Fischinger's "Toccata \& Fugue in D Minor" in Disney's 1940 film, Fantasia.

Fernand Léger and René Clair, on the other hand, conveyed the mechanical rhythms of modern life through editing. Leger emphasized the purity of his intentions in describing his masterpiece, Ballet Mécanique (1924) thus: "No scenario. The interactions of rhythmic images that is all." ${ }^{32}$ René Clair in 1923 wrote more broadly of the lure of cinematic motion: "The public loves movement ... the action graded by the disposition of images." ${ }^{33}$ Qualifying "movement," he further commented about Ballet Mécanique, "I do not say movement registered by the image itself, but the movement of images one in relation to another." ${ }^{14}$ This effect of movement was achieved in both films through the use of montage editing. Karen Pearlman describes this process as "the assembling of images and sounds into relations that generate rhythms, ideas and experiences of a whole." ${ }^{\prime 35}$ The audience comes to experience motion through montage, not just through the movement of captured images, but additionally through the carefully orchestrated structuring of individual shots in the edit. The temporal and spatial inter-relationships that pass before audiences' eyes create rhythms and dynamics, which are subsequently experienced as movement. Although there is a human presence in both of these films, objects are also set moving about the frame through jump cuts. That these filmmakers played on the association between movement and dance is obvious from Ballet Mécanique's title, whereas Claire's film, Entracte, (1924) becomes relevant through its context, as it was played in the intermission of Francis Picabia's ballet, Relâche (1924).

Although it is Ballet Mécanique that Christopher Green refers to as an "experiment in the controlled creation of movement," ${ }^{136}$ this statement encompasses the ethos of the entire Screendance practice. The field's cementation of avant-garde filmmaking practices with its own is a shrewd move as it provides screendance with even greater ties to film art. In addition, it provides the cinematic origins of the field's continued exploration of dance, not necessarily through the body, but absolutely through the kinetic.

\section{Metaphor}

Another means through which screendance corresponds with the non-human via dance is through the use of metaphor and analogy. Scholars Lisanne van Weeldon et al. explain how metaphors work linguistically. They write: "one object, the target is compared to and understood in terms of another object, the source ... perceptual similarity between two objects enhances a conceptual link between the two." ${ }^{137}$ Our ability to perceive dance in many Radical Screendance works functions similarly, as in the absence of "recognizable" dance content, the "conceptual links" that must be made in order that we perceive dance nonetheless become consciously embedded into the work by the filmmaker. The intentionality of filmmakers in devising and articulating metaphors, as well as our act of deciphering them, is central to an audience's understanding of dance's significance within these works. 
Whereas some works interweave an element of metaphor into the larger complex of the work, Spin! (2009) by Constanti Georgescu serves more as a grand performance of metaphor, as well as a metaphor for performance, in which the "target" is spinning tops and the "source" is ballet. Georgescu is an interdisciplinary artist who specializes in choreography, performance, and video art. Spin! is a five minute excerpt, taken from a larger "video-dance performance" entitled Remake, premiered at Theatre Bremen in 2008. What began as a "three hour spinning top jam-session" 38 in performance ends up the content of a film, in which spinning tops triumph in a "balletlike" spectacle, to the music of Beethoven.

All aspects of the mise-en-scène in Spin! serve to produce metaphorical links. The setting, a sea of pristine white, like a world of icing sugar, is home to a corps de spinning tops, each and every one as vibrantly red as Moira Shearer's shoes. The film is instantly reminiscent of a grandiose ballet, fading up through a moment of white, like the opening of curtains; the establishing moments make full use of the dynamics of the music to mark the introduction of a single defocused top, which spins in flutters, center frame. The metaphorical performance thus begins. The idea of a show becomes further enhanced through the cinematic process in several ways. Georgescu uses a conventional style of shooting and editing that emphasizes the movement inherent to the objects themselves, through fixed frames and longer shot durations. The tops are presented from few angles: head on, or through an oblique top shot. This conventionality forges associations between the generic space and that of a performance space, as shooting from a fixed fourth wall mirrors the set-up not just of traditional theatrical event coverage, but also the audience's position within a proscenium arch theatre. Within this visual confinement, however, Georgescu makes a clever selection of shots that encourage the audience to make very specific connections. Those shots, which feature a single top or inflect one amongst others, conjure the hierarchical ranks of the ballet company, with the most prominent object being that which spins most rigorously, evoking the soloist. This impression takes on an air of parody, as a sudden whirl of entrances bumps the centralized top out of the limelight. Once the metaphorical links have been sewn, we appear to read further similarities into events automatically, elaborating our interpretation so that the nib of the tops become pointe shoes, the revolutions "fouette" turns, and the curve of the spinning top the ballerina's tutu. We relish too, the moments of harmony, when two tops spin in sync as if performing a pas de deux.

The edit similarly serves to feed the trope. The cuts are clean, working to provide fresh moments as well as to create a synchronicity between the visuals and the score. Although the film is in fact just a basic montage, the uncompromising drive of Beethoven's score functions as the master structure of the work, to which the visuals are matched in post-production. We consequently perceive the impression of a tightly choreographed performance through what is essentially the unpredictable movement of spinning tops. This choice of dramatic score, beyond the histrionics it adds, works to further cement theatrical connotations. When all these facets are put to work, we experience a full blown ballet-like experience through childhood toys. 
A work like Spin! does not ask that we abandon our conventional notions of dance, but rather that we use these as a reference point from which to engage our imaginative understandings of the concept. It is this perceptual and conceptual interrelating that conjures such a strong impression of the flesh of the dancer though the spectacle of wood and lacquer. Films of this nature offer us the chance to explore the prolific life of dance through the pliancy of our perception. As Jones writes, "anthropomorphism, metaphor and analogy can provide valuable ways of achieving understanding of what might be meant by this term 'dance' into its variety." ${ }^{39}$

\section{Choreography}

One of the more obtuse relationships between dance and screendance derives from an approach to filmmaking that is based on affinities perceived between the processes of making a film and making a dance. Removed from the confines of the dancing body, choreography becomes a transportable process that "anyone can access." ${ }^{\prime 40}$ In the same way then that we might carry out a queer analysis to engage with a film or text from a particular perspective, we might approach filmmaking through the experiential framework of choreography. The potential that this type of dance and filmmaking connection can offer to screendance artists is vast, as a choreographic framework can be employed at any stage of the filmmaking process. In her book Dancefilm: Choreography and the Moving Image, Erin Brannigan calls the result a "filmic performance" in which "the choreographic quality of the dancefilm can be considered in relation to both the profilmic and filmic elements." 41 The conceit, as Laleen Jayamanne further articulates, reads as follows: "In film the lighting, editing, camera distance, and movement are equally potent 'performers."'42 In theory this means that any aspects of a film's process can be choreographed by its maker. In practice, the approach that artists make will largely be influenced by their own experience of dance-making and their conceptions about how it might inform the filmmaking process. It is not surprising, then, that screendance works that take such an approach are also referred to as "choreocinema" or "cinechoreographies."

This choreographic methodology, then, is the filmmakers' conceptual transposition of pre-existing filmic processes, in which "the cinematic process" becomes "written through by a variety of choreographic operations." ${ }^{43}$ This approach can therefore remain difficult to discern from, say, a film that features movement, which has not applied such a focus. For now this conceptual approach means that anything could potentially be interpreted as being screendance, highlighting a need for further studies that might explore any tangible results of screendance's use of a choreographic approach to filmmaking. The differences are certainly subtly qualitative, sometimes so much so that their effect is barely perceptible in the end product. For this reason, the following analysis draws heavily on the words of the filmmakers, as their language reveals a lot about the ways in which they perceive choreography to relate to their filmmaking. 
The kind of "filmic performance" that British filmmaker David Hinton affects with Birds (2000) comes from adopting a choreographic approach to editing. This is possible due to similarities between the formal construction of dance and film. Hinton posits:

On a very fundamental level, making a film and making a dance are a very similar kind of activity; they're both about giving structure to action. If you think of film as just a formal language ... you can look at any film as a dance film. All films take images of action and try to put these images together in a rhythmic and expressive way. In this sense film and dance work along the same lines. ${ }^{44}$

As a non-dancer/filmmaker, Hinton represents a growing number of filmmakers lured to screendance by its "open territory." ${ }^{45}$ Hinton speaks of a "richness ... where you can still try all these things; it hasn't in anyway become formulaic." ${ }^{46}$ As a filmmaker without any experiential, embodied knowledge of dance, his take on both dance and choreography assumes the structural air of one who specializes in the assemblage of images. He subsequently states:

Film editing gives you everything that a choreographer wants, the ability to select any movement that you want on the face of the earth and give shape to it in any way that you want, as soon as you have movement in the cutting room, it's completely under your control, you can decide exactly where you want that movement to begin, where you want it to end. ${ }^{47}$

According to one of Dance Films Association's directors, Marta Renzi, Hinton advocates three practical approaches to creating screendance. Either "Begin with a previously choreographed dance," "create the 'structure of action' simultaneously in dance and film," or else "'Harvest' movement, creating the structure of action in the editing room. ${ }^{\prime \prime 8}$ Birds conforms to the latter practice, as "All of the language that is being used is film language."49 The result is that the film relies on a "purely cinematic means to make a dance" 50 and the more you watch, the more it comes becomes one.

Hinton created Birds using montage editing. This style of composition enables him to structure random archive images of birds into a syntactically coherent dance of visual and audio rhythms. If we view choreography as "the art of manipulating movement: phrasing its time, space, and energy into affective forms and structures," ${ }^{51}$ the montage functions similarly, crafting individual shots of moving birds together, like steps, to form a series of relations that are punctuated across time and space into phrases and that extend to comprise the larger choreographic structure. Separate images are further cut together using repetition and juxtaposition to form intricate rhythmic patterns of movements, which mirror the construction of motif and phrasing in dance. For example, in the opening section, set in a forest, shots that accentuate side to side motions are choreographed intermittently with those of birds moving downwards into frame or articulating circular pathways with their wings. These 
patterned phrases are then often recycled, adding layers of rhythmic complexity to the overall structural design.

Hinton also manufactures a continuity of movement by joining what are in fact disparate images, captured at different places and times, into an illusion of coherence. "I'm cutting it so that the movement is continuous; it feels like there's one movement, so you have a kind of continuity, but continuity with transformation at the same time." ${ }^{22} \mathrm{~A}$ shot of two birds in chase pans to contain them as they skim swiftly right to left across the water. This is then cut with a shot of a different bird, also travelling right to left in relation to the frame, also flying low over water, then three birds running right to left on the water itself. If you look at the backgrounds of these shots, their disconnection becomes apparent; they have been captured at different locations and at different times. Yet what you more readily perceive is a fluid spatial and temporal progression of motion across a horizontal pathway that mirrors the processes of dance construction, whose phrases, too, articulate a continuity of motion through moments of change. This is one of Hinton's achievements: that the movement of birds becomes comprehensible through precisely those self-same concepts that we use to approach even the most "intentional action" of a dancer. And this is precisely the kind of connection that you are meant to make: "The point to me, is that every principle that is applied to birds in this film, could be applied to dancers." ${ }^{53}$

Yet the film works not only on a formal and metaphorical level, but on a deeper philosophical plane also. Hinton's choice of ornithological content initiates poignant anthropomorphic contemplation. The beauty of the movement within each individual shot, as well as the satisfying sense of fluid unity, ultimately undermines the centrality of man's place within dance. The hugely ornate textures created by the waves of birds flying in formation, swelling and retracting in a paradox of chaotic order, not only degrades our own attempts at the orchestration of movement, but highlights the artificial nature of human practices such as choreography, performance, and filmmaking. Hinton comments, "one of the things that these birds represented for me, is totally authentic movement, because the bird does not know that it's putting on a performance." The film leads us to a conclusion that advocates of dance as "human intentional action" would find sobering. For even should we wish to mimic the dancelike movements of these birds, as Hinton suggests we could, in reality our "intentional" dance could never touch the levels of sophistication, precision, or indeed beauty, that the instinctive non-dance movements of birds achieves without effort. And yet there is a clever irony that lies beneath the ponderings that Hinton's choreographic approach to filmmaking sets up. For despite the formidably instinctual movement that fill each and every frame in Birds, these creatures only ever set flight as a direct consequence of the conscious, man-made processes of filmmaking.

\section{A Somatic Approach To Film-Making}

Another way in which screendance relates to dance is through a somatic approach to the making of a film. Somatic, here, does not mean privileging the body at 
the expense of thought, but rather an approach to filmmaking that initiates at the body. Brannigan calls this a "dancerly" approach, ${ }^{54}$ through which the "physical thinking, ${ }^{\prime \prime 5}$ as well as the corporeal experience of dance and choreography, becomes transferred onto the process of filmmaking in much the same way that a seasoned musician might approach it through the ears. We might best acquire an understanding of the nature of somatic perception through the words of Claudia Kappenberg. She describes the approach as "coming from the inner to the outer ... Choreography not as working with bodies, it is the body, an inner-attitude." ${ }^{156}$ Chirstinn Whyte describes this corporeally-centered way of experiencing the world, as having "dance-informed eyes," 57 which, in terms of screendance making, means making decisions as a filmmaker through the internal experience of dance and choreography.

After her initial role as a dancer alongside the likes of Martha Graham, Hanya Holm, and Anna Sokolow, Shirely Clarke turned to filmmaking in $1953 . .^{58}$ Despite her status as a prolific contributor to the American underground film scene, through her award winning feature length documentaries and dance films, the "dancerly" stamp of her aesthetic is interpreted throughout her oeuvre. Henry Breitrose, writing for Film Quarterly in 1960, thus wrote, "Clarke was originally a dancer. Before making films she took the precaution of learning a great deal about film technique; but she remains an instinctual filmmaker, whose feeling for movement generally seems to have carried over into her feeling for the camera." ${ }^{159}$

Clarke's early screendance work, Bridges-Go-Round (1958), replaces the dancing body with the bridges of New York City. What makes this work especially pioneering is Clarke's early reference to its status as a screendance work, despite its lack of bodies. According to Clarke, the film, "simply establishes the fact that you can make a dance film without dancers." ${ }^{60}$ The film was created as "little bits of Americana, ${ }^{\prime \prime 1}$ for exhibition at the United States Pavillion, as a part of the 1958 Brussels World Fair. Although like Hinton, Clarke spoke of "the choreography of editing and the choreography of space/time," her dance perspective results in a further embodied approach to the orchestration of shots and the movement of the camera. She comments, "By choreographing the camera itself, you can add a whole new level of dance." ${ }^{162}$ She thus perceived the timing, quality, and spatial progression of camera movement as choreographic tools.

You can sense her dancerly approach to her subject, through the careful orchestration of fluid pans, tilts and zooms that circle and sweep about these giant structures with an effortless lyricism. The camera (and Clarke's body behind it) thus becomes one of the central characters in Clarke's filmic performance, for although they cannot be seen, there is a profound sense of their tangible presence throughout. A choreographic approach is further applied throughout the edit, through which Clarke further composes her moving images into visual rhythms. The shots are superimposed into delicate layers that ellipse and elide in smooth counter directions, so that the monuments of New York City seem to dance with one another. Changing color tints add further rhythmic punctuation, adding to this kaleidoscopic waltz comprised of immovable metal. As Henry Breitrose noted, "the bridges become plastic materials for 
a highly abstract subjective study in structures and movements ... the great steel girders, the taut cables, the towers and railings and roadways and abutments seem almost to dance." 63

Becky Edmunds description of This Place (2008) as "A rhythmic and patterned document of place" 64 would befit Bridges well. The work is the manifestation of Edmunds's interest in work that "might not have a theatrical dancing body in the shot, but which is very much influenced by dance and dance practice." ${ }^{15}$ Chirstinn Whyte comments, "Becky Edmunds sidesteps the issue of 'dancer-as-subject' by using aspects of environment as choreographic raw material." ${ }^{66}$ Shot at PACT Zollverein, a disused colliery converted into a performing arts school in Germany, the film too deals in brick and metal. Edmunds also echoes Clarke's choreographic approach to the camera. She states: "I got very interested in what is it that I'm choreographing when I'm choreographing. Am I choreographing a body in the frame, or am I choreographing the space around the body, or am I choreographing the camera itself?"67 Although Bridges and This Place correlate, it is Edmunds' even deeper conceptual connection of both choreography and embodiment within her practice that, she believes, makes her work "absolutely about choreography." 68

Edmunds struggles to verbally explicate this correspondence high-lighting, once again, the difficulty an audience might have appreciating such works. If we consider the function of choreography within her filmmaking process, we understand why.

I can use it (choreography) as a way of looking at something ... and if I use my definition of choreography to look at something, then it will enable me to notice certain things about it ... I will obviously notice movement, but I will also notice rhythm and pattern ... and also maybe I will then notice the relation of my own body to the thing I'm looking at ... just by looking at it with the notion of choreography ... often if I look at something and I really don't understand it, I'll look at it as a piece of choreography to see if it helps bring something out. ${ }^{69}$

Adopting a choreographic approach to filmmaking for Edmunds serves not just as means of perceiving the operations of film-making, but as a way of understanding the world. She describes it as though it were a pair of glasses that can be taken on and off, adding clarity when needed or discarded when a different vision is required. The choreographic is thus used as mode of perception, which Edmunds adopts within her larger research in embodied "looking." She states, "I found myself in an extraordinary place ... and I was practising looking." ${ }^{170}$ This statement serves as the ideal synopsis for This Place, a work that reveals its alien environment from a whole host of perspectives.

Like Whyte, the eyes form part of Edmunds embodied approach to filmmaking. She thus states, "It is a physical practice, and that physicality very much includes the eyes and the behaviour of the eyes, and practice in looking and being able to recognise something. ${ }^{171}$ This sense of physical seeing is eerily palpable in This Place, through its probing, tentacle-like use of camera and twitching images that stutter like 
blinking eyes. Although there is no body in sight, we sense the presence of the "looker." Edmunds also considers the interrogation of her bodily positioning within an environment as forming part of her choreographic method, enabling her to further navigate her way through the filmmaking process, affecting the choices she makes and providing fresh perspectives. She asks, "If I put my body in a big space would something change: could I find my way to a wide shot, and to the body in wide shot"? ${ }^{72}$

Every aspect of This Place serves as an opportunity for Edmunds to reveal a new aspect of her embodied sight. Whereas Bridges used the physicality of the moving camera and the layering and pacing of images to convey harmony, This Place disorients. Over the opening glimpses of industrial architecture that wax and wane, for example, we hear the sounds of a forest. The shots also de-familiarize through obtuse angles and reflections, confusing up from down, right from left and real from unreal. The strong sense of unfamiliarity and curiosity within the space comes in part from Edmunds' insistence that the process be as un-premeditated as possible, so that her reactions to the places she films are somehow "real" and in-the-moment. The effect is one of profound interrogation and exploration not so dissimilar to the introspective mind-body improvisation of William Forsythe. The film serves as an affective manifestation of Edmund's refusal to assume a fixed point of knowledge through a multitude of fragmented perspectives that seem to disallow that we ever know for certain where we are and what it is that we see before us. What we experience, then, is a journey built out of a journey: an exploration of the unknown, manufactured through the embodied responses of a filmmaker to her environment. Although the film's relevance to choreography functions more to enable the artistic process of its maker than as a discernable feature of the work in this instance, the categorization of this work as screendance emphasizes the complex relationships that dance can manifest within current practice.

The evidence suggests that audiences do possess much of the requisite cognitive stock to access Radical Screendance works but that the implications that some of the more esoteric choreographic approaches to screendance making have on identification and intentionality might benefit from further enquiry. A vital part of audience's appreciation of Radical Screendance lies in accepting its rejection of dance in any "strict sense" in favor of a wealth of possible meanings. It is as such that we are able to frame the links between the non-human and dance within its practice. Furthermore, screendance's move away from a traditional understanding of dance does not mean that it becomes divorced from an audience's understandings of the term. Rather, the clue for unlocking screendance lies, ironically, in engaging with our inherently multifaceted relationship with dance, one which is capable of embracing the concept as metaphor, process, attitude, and construct. The role of this cuttingedge visual practice is thereby significant, as the understanding and indeed construction of its works require that we question, stretch, and ultimately enjoy confronting the rigidity of our ideas about what dance and film-making can be. 
Radical Screendance is not necessarily instantly identifiable, nor is its relation to dance always easy to decipher, but that's precisely the point.

\section{Notes}

1. Chirstinn Whyte, Shiftwork (n.d), accessed May 8, 2011, http://www.shiftwork.org.uk/unspooled_site/outlying/content.html.

2. Douglas Rosenberg and Claudia Kappenberg, The International Journal of Screendance 1 (Summer 2010), accessed May 8, 2011, http://journals.library.wisc.edu/index.php/screendance/article/viewFile/316/310.

3. Claudia Kappenberg, "Does Screendance need to look like dance?" (2009), accessed April 20, 2011, http:/www.dvpg.net/docs/ckpaper_DanceasFilm_19 May09pdf.

4. David Hinton in Liz Aggiss, Take7 (2008).

5. Becky Edmunds, Lucy Cash and Claudia Kappenberg, "What if... we could view all this as dance," in Crossing Borders (2010), accessed September 3, 2014, http://www.independentdance.co.uk/programmepage/exchanges/crossingborders/crossing-borders-talks-media-archive/.

6. Graham McFee, Understanding Dance (London: Routledge, 1992), 134.

7. Ibid, 39.

8. Douglas Rosenberg, "The Work of Dance in the Age of Corporeal Reproduction" (2010), accessed September 3, 2014. http://www.dvpg.net/docs/adfessay.pdf.

9. McFee, Understanding Dance, 16.

10. Sue Jones, "Do Rabbits Dance? A Problem Concerning the Identification of Dance," in Dance, Education and Philosophy, edited by Graham Mcfee (Oxford: Meyer \& Meyer Sport, 1999), 85.

11. David Carr, "Thought and Action in the Art of Dance," British Journal of Aesthetics 27, no.4 (1987): 347.

12. Jones, “Do Rabbits Dance?", 97.

13. Francis Sparshott, "On Knowing What Dancing Is," Dance, Education and Philosophy, 72.

14. Ibid., 81.

15. David Best, Expression in Movement and the Arts: A Philosophical Enquiry (London: Lepus Books, 1974), 41. 
16. Sparshott, "On Knowing," 74.

17. Ibid., 74.

18. Jones, “Do Rabbits Dance?", 85.

19. David Carr, "Thought and Action in the Art of Dance," British Journal of Aesthetics 27, no. 4 (1987): 345-357.

20. Jones, “Do Rabbits Dance?", 86.

21. Latika Young, "In Search of a Name," Dance Films Association, Inc, (2009), accessed May 8, 201, http://www.dancefilmsassn.org/Linkezine3-408.html.

22. Amy Greenfield in Claudia Kappenberg, "Does Screendance need to look like dance?" (2009), accessed April 20, 2011, http:/www.dvpg.net/docs/ckpaper_DanceasFilm_19 May09pdf.

23. Rosenberg and Kappenberg, The International Journal of Screendance, n.p.

24. Becky Edmunds, This Place (2008), accessed September 10, 2014, http://www.youtube.com/watch?v=TkSj3TDFPIU.

25. Whyte, Shiftwork, n.p.

26. Graham McFee, The philosophical aesthetics of dance: identity, performance and understanding (England: Dance Books, 2011), Kindle edition, loc. 2566.

27. J. Anderson in Mary M Smyth "Kinesthetic Communication in Dance" in Dance Research Journal 16, no.2 (Autumn 1984): 19.

28. Lorettann Devlin Gascard, "Motion Painting: 'Abstract' Animation as an Art Form," Leonardo 16, no.4 (Autumn 1983): 293.

29. Fernand Léger in Christopher Green, Leger and The Avant-Garde (UK: BAS Printers Limited, 1976), 56.

30. Kraucer qtd. in Whyte, Shiftwork, n.p.

31. Marcel Schwierin and Sandra Naumann, "Absolute Film," n.d., accessed May 8, 2011. http://www.see-this-sound.at/compendium/abstract/53.

32. Qtd. in Green, Leger and The Avant-Garde, 281.

33. Qtd. in ibid., 278.

34. Ibid., 279.

35. Karen Pearlman, Cutting Rhythms: Shaping the Film Edit (Oxford: Focus Press, 2009), 155.

36. Green, Leger and The Avant-Garde, 282. 
37. Van Weeldon et al, "Perceptual Similarity in Visual Metaphor Processing," n.d, accessed September 5, 2014, http://www.spatialcognition.de/CSP/ vanWeeldon.pdf.

38. Anon, "Spin!" (n.d) accessed September 3, 2014, http://www.migrations.co/article22-SPIN.

39. Jones in McFee, Dance, Education and Philosophy, 98.

40. Ibid.

41. Brannigan, Dancefilm: Choreography and the Moving Image (New York: Oxford University Press, 2011), viii.

42. Qtd in Brannigan, Dancefilm, viii.

43. Ibid.

44. Qtd. in "Program 11-111: Dance Film Artist in Focus: David Hinton (in person)," St. Petersburg International Dance Film Festival "Kinodance"(2006), accessed August 5, 2014, http://www.kinodance.com/russia/films_program2_2006.html.

45. Hinton in Take7.

46. Ibid.

47. Ibid.

48. Qtd. in Marta Renzi, "Can I Be a Canadian?" n.d, accessed January 4, 2011.

http://dancefilms.org/2010/10/24/dfa-dance-on-camera-journal

49. Hinton "Part 09 Birds," n.d., accessed May 6, 2011, http://www.southeastdance.org.uk/podcasts/podcasts.html.

50. Ibid.

51. Pearlman, Cutting Rhythms, xxii.

52. Hinton, "Part 09 Birds," n.p.

53. Ibid.

54. Brannigan, Dancefilm, viii.

55. Pearlman, Cutting Rhythms.

56. In Edmunds, Cash, and Kappenberg, "What if...", n.p.

57. Whyte, Shiftwork, n.p.

58. Bruce Bebb, "The Many Media of Shirley Clarke," Journal of the University Film Association 34, no. 2 (Spring 1982): 3.

59. Henry Brietrose, "Films of Shirley Clarke," Film Quarterly 13, no.4 (1960): 57. 
60. Shirley Clarke qtd. in Lauren Rabinovitz, "Choreography of Cinema: an interview with Shirley Clarke," Afterimage (December 1983): 8-11, accessed May 8, 2011, http://www.vasulka.org/archive/4-30c/AfterlmageDec83\%28300\%29.pdf.

61. Ibid.

62. Ibid.

63. Brietrose, "Films of Shirley Clarke," 57.

64. Edmunds, This Place (2008), n.p.

65. In Edmunds, Cash, and Kappenberg, "What if...", n.p.

66. Whyte, "Hybrids," in Filmwaves (2009), accessed May 1, 2011, http://www.filmwaves.co.uk/index.php?option=com_content\&view=article\&id=211:h ybrids-becky-edmunds\&catid=78:dance-and-film\&ltemid $=2$.

67. Edmunds in ibid.

68. Ibid.

69. Ibid.

70. Edmunds, "Seeing anew," RealTime 77 (Feb-March 2007), accessed April 22, 2011, http://www.realtimearts.net/article/issue77/8345.

71. Edmunds in Whyte, "Hybrids," n.p.

72. Ibid.

\section{References}

Anonymous. SPIN! Accessed September 3, 2014. http://www.migrations.co/article22SPIN.

Bebb, Bruce. "The Many Media of Shirley Clarke." Journal of the University Film Association 34, no. 2 (Spring 1982): 3-8.

Best, David. Expression in Movement and the Arts: A Philosophical Enquiry. London: Lepus Books, 1974.

Brannigan, Erin. Dancefilm; Choreography and the Moving Image. New York: Oxford University Press, 2011.

Breitrose, Henry, “Films of Shirley Clarke." Film Quarterly 13, no. 4 (1960): 57-58. 
Carr, David. "Thought and Action in the Art of Dance." British Journal of Aesthetics 27, no. 4 (1987): 345-357.

Edmunds, Becky. "Seeing anew." RealTime 77 (Feb-March 2007): 36.

Edmunds, Becky, Lucy Cash, and Claudia Kappenberg. "What if...we could view all this as dance." Crossing Borders (2010). Accessed 2 September 2014.

http://www.independentdance.co.uk/programmepage/exchanges/crossingborders/crossing-borders-talks-media-archive/.

Gascard, Lorettann Devlin. "Motion Painting: 'Abstract' Animation as an Art Form." Leonardo 16, no. 4 (Autumn, 1983): 293-297.

Green, Christopher. Leger and The Avant-Garde. UK: BAS Printers Limited, 1976.

Hinton, David. "Part 09: 'Birds'” (2009). Accessed 6 May, 2011. http://www.southeastdance.org.uk/podcasts/podcasts.html.

Jones, Sue. "Do Rabbits Dance? A Problem Concerning the Identification of Dance." In Dance, Education and Philosophy, edited by Graham Mcfee, 85-99. Oxford: Meyer \& Meyer Sport, 1999.

Kappenberg, Claudia, "Does Screendance need to look like dance?" (2009). Accessed April 20, 2011.http://dvpg.net/docs/CKpaper_DanceasFilm_19May09.pdf.

Lund, Cornelia. "Cinedance, Dance in Cinema, and Dancing Cinema." See This Sound. (n.d). Accessed August 8, 2014. http://www.see-thissound.at/compendium/abstract/50.

McFee, Graham. Understanding Dance. London: Routledge, 1992.

---. Dance, Education and Philosophy. Oxford: Meyer \& Meyer Sport, 1999.

---. The Philosophical Aesthetics of Dance: Identity, Performance and Understanding. England: Dance Books, 2011. Kindle edition.

Pearlman, Karen. Cutting Rhythms: Shaping the Film Edit. Oxford: Focus Press, 2009.

Renzi, Marta, "Can I Be a Canadian?" n.d. Accessed Jan 4, 2011.

http://dancefilms.org/2010/10/24/dfa-dance-on-camera-journal.

Rabinovitz, Lauren. "Choreography of Cinema: an interview with Shirley Clarke."

Afterimage (December 1983): 8-11. Accessed May 8, 2011.

http://www.vasulka.org/archive/4-30c/AfterlmageDec83\%28300\%29.pdf.

Rosenberg, Douglas and Claudia Kappenberg. The International Journal of

Screendance 1 (Summer 2010). Accessed May 8, 2011.

http://journals.library.wisc.edu/index.php/screendance/article/viewFile/316/310. 
Rosenberg, Douglas. "The Work of Dance in the Age of Corporeal Reproduction." 2001. Accessed September 3, 2011. http://www.dvpg.net/docs/adfessay.pdf.

Schwierin, Marcel and Sandra Naumann. "Absolute Film." n.d. Accessed May 8, 2011. http://www.see-this-sound.at/compendium/abstract/53.

Smyth, Mary M. "Kinesthetic Communication in Dance." Dance Research Journal 16, no. 2, (1984): 19-22.

Sparshott, Francis. "On Knowing What Dancing Is," in Dance, Education and Philosophy, edited by Graham McFee, Chapter 5. Oxford: Meyer \& Meyer Sport (UK) Ltd., 1999.

Van Weeldon, Lisanne et al. "Perceptual Similarity in Visual Metaphor Processing." n.d. Accessed May 8, 2011. http://www.spatial-cognition.de/CSP/vanWeelden.pdf.

Whyte, Chirstinn. "Hybrids." Filmwaves. December 10, 2009. Accessed 1 May, 2011. http://www.filmwaves.co.uk/index.php?option=com_content\&view=article\&id=211:h ybrids-becky-edmunds\&catid=78:dance-and-film\&ltemid $=2$.

---. Shiftwork. n.d. Accessed September 8, 2014.

http://www.hiftwork.org.uk/unspooled_site/outlying/content.html.

Young, Latika, "In Search of a Name." Dance Films Association, Inc. 2008. Accessed September 2, 2014. http://www.dancefilms.org/dance-on-camera-journalarchives/dance-on-camera-march-april-08-2/.

\section{Media}

Bridges-Go-Round(1958). Dir. Shirley Clarke. Accessed May 8, 2011. http:www.youtube.com/watch?v=084hQ3_viYw.

SPIN! (2009). Dir. Constanti Georgescu. Accessed April 20, 2011. http://vimeo.com/8145005.

This Place (2008). Dir. Becky Edmunds. Accessed September 10, 2014. http://www.youtube.com/watch?v=TkSj3TDFPIU.

Birds (2000). Dir. Hinton, David. Part of TAKE7 (2008). Dir. Liz Aggiss. 